\title{
Between the Religious Tolerance and Confessional Loyalty: The Orthodox Church in the Polish-Lithuanian Commonwealth from John Herbinius' Point of View
}

\author{
Nataliia Sinkevych \\ Eberhard Karls University of Tübingen, Tübingen, Germany
}

\begin{abstract}
John Herbinius (1633-1679) was a well-known Lutheran theologian and writer. Living long time on the territory of Polish-Lithuanian Commonwealth (in contemporary Vilnus), he wrote a description of the Kyiv religious caves, which was published in 1675 in Jena. The purpose of this research is to contribute to the further understanding and interpretation of the church history and inter-confessional relations on the territory on the Polish-Lithuanian Commonwealth in the middle of the 17th century, and its later influence on historical and cultural development. Herbinius, being deeply connected with the West-European Protestant world, and at the same time, living in multi-cultural and multi-religious Vilnius, tried to maneuver between the religious tolerance and confessional loyalty, the adherence to the ideas of German reformation and a personal friendship with the Orthodox clergy. The methodology of this work includes historical, inter-confessional, heuristic, biographical, reader-orientated, and linguistic approaches, textual, contextual, and comparative analysis. This article has shown that the Protestant author percepted and treated the Orthodox Church in a very positive way: Church customs, canonical law, and discipline, clergy, and even monasticism did not provoke any criticism from his side. However, on the questions of iconolatry and confessional exclusivism of the Orthodox Church Herbinius could not refrain from criticism. They evidently contradicted his views on real Christian piety and religious tolerance.
\end{abstract}

Keywords: John Herbinius, Kyiv monastery of the caves, the Eastern Orthodox Church, confessional dialogue, religious tolerance

\section{Introduction}

Since the Great Schism (1054) and the IV Crusade (1202-1204), Eastern and Western Christianity had considered each other heterodox. The first list of differences between Eastern and Western Christianity is contained in a letter from Pope Nicholas I (820-867), according to which the Byzantines accused Latins of: fasting on Saturdays, Filioque, celibate of a clergy, allowing confirmation only by bishops, mixing chrism with running water, wrong fast at the Lent, the blessing and offering a lamb on the altar at Easter, shaving off beards, ordination of deacons directly to bishops (Kolbaba, 2008, p. 133).

An interest towards the Eastern Christianity appeared only in humanists' milieu. The admiring of Greek language and Patristic tradition created an opportunity to broaden the knowledge about the Greek Church. Even Moscow Church became an object of some interest as well. Johann Fabri's Moscovitarum religio (1526) was,

Nataliia Sinkevych, Ph.D., Department of Protestant Theology, Eberhard Karls University of Tübingen. 
in fact, the first study about the Orthodox Church based on author's communication with Moscow envoys.

Reformation completely changed the attitude to Orthodox Church, considering it as an alternative to Roman Catholicism. Protestants had a great impact on studies of the Orthodox theology and even developing of Slavic languages (Lemberg, 1985, p. 81). Martin Luther himself did not regard the Greek Church as heretical and referred to its practical experience and tradition which he saw universally ecclesiastical. Moreover, Luther considered the Greek Church as more powerful compared to the Roman Church which had lost its spiritual influence because of Pope's superiority (Benz, 1952, pp. 10-14). Already in 1519 discussion with Johann Eck, Luther referred to the existence of the Orthodox Church, denying Pope's claims to represent the whole Christian community (Michalski, 1993, p. 104). Later, Lutheran Joachim Westphal (1510-1574), arguing with Calvin about the physical presence of Christ in the Sacraments, appreciates the authority of Greek Church: Et comperimus non tantam Romanam Ecclesiam affirmare corporalem praesentiam Christi, sed idem et nunc sentire et olim sensisse Graecam Ecclesiam, ut testatur Canon Missae apud Graecos (Westphalus, 1555, p. 20). The special examination of the Orthodox doctrine, written in 1569 by David Chyträus (1530-1600) underlined the main differences between the Orthodox and Protestant theologians: the question of salvation through faith, the necessity of good deeds, the effects of redemption, and the veneration of icons (Michalski, 1993, p. 110).

The most famous contact between Lutherans and Orthodoxs in the 16th century is 1574-1581 epistolary of Tübingen professors Jacob Andreae, Lucas Osiander, Jacob Heerbrand, and Martin Crusius from one side and Ecumenical patriarch Jeremias II of Constantinople from another one. The contact started as a German missionary intention in the Turkish Empire. The mission, headed by Stephan Gerlach, arrived 1573 to Constantinople and delivered the first letter from Tübingen Lutherans (Wendebourg, 1986, pp. 31-151). This and two further letters were concentrated mainly on the theological questions of Confessio Augustana; they were answered by the Patriarch and showed the following confessional antagonisms: the Proceeding of the Holy Spirit (Filioque), the free will and good deeds, the veneration of saints and icons, the monasticism, the sacraments, and the Church tradition (Wendebourg, 1986, pp. 207-346).

Thus, the theological discussion between Tübingen Lutherans and Constantinople Patriarch Jeremias II Tranos might be called inefficient. Fifty years later, another Constantinople Patriarch Cyril Lukaris (1572-1638), who had studied in West-European Protestant and Catholic universities, searching for the way to reform the Orthodox Church and being deeply involved in European and Ottoman politics, started to correspond with the Calvinist and Anglican Theologians. Proclaimed by him and published in 1629 in Geneva Confessio which connection to Protestantism has been discussing among theologians till nowadays. Obvious is the influence on Lucaris of the Calvin's teaching on original sin, free will, baptism, good deeds, purgatory, predestination, and even veneration of icons (Pichlner, 1862, pp. 180-208). These views, however, remained to be Cyril's own ones-1638 the council of Constantinople excommunicated Cyril; Geneva Confessio was several times proclaimed by the Orthodox theologians to be a not-orthodox.

Thus, recurring contacts between Protestant Europe with the Orthodox Constantinople provoked a certain dialogue between the theologians of two denominations, yet it did not develop into some consensus. Though still important in the Orthodox world but captured by the Ottoman State Patriarchate of Constantinople was very uncertain and unsafe place for theological discussion. In the 16th century, the new centre of the Orthodox Church appeared on the North-Eastern borderland of Europe. Visiting Moscow in 1589, the already mentioned Patriarch of Constantinople Jeremiah II under the evident political pressure of Moscow Tsar proclaimed the 
establishment of a new Orthodox Patriarchate with the centre in Moscow. The idea of "Moscow一the third and the last Rome", that appeared a shortly before, gave the Moscow citizens (and mainly its rulers) the confidence of being the only and true Orthodox Christians (Синицына, 1998). Taking into account this fact and the absence of universities as podiums for theological discussions and closeness of the borders of Moscow state, the Orthodox-Protestant dialogue in the country had not many occasions. Nevertheless, one of the attempts to such a dialogue was made 1570 by the member of Bohemian Brethren Jan Rokita who travelled to Moscow and had a discussion with the Grand Prince Ivan IV the Terrible (1530-1584) on the Christian dogmatic. In fact, the Tsar retold the 1570 anti-Lutheran treatise of Parfemii Iurodivyi of Suzdal who had very little knowledge about European Protestantism (Michalski, 1993, pp. 135-136). This polemic later was translated to the reader through the work of Polish Reformed author Jan Łasicki De Russorum, Moscovitarum et Tartarorum religione, sacrificiis, nuptiarum funerum ritu. Łasicki himself demonstrated a strongly negative attitude to the Moscow Princedom and the Orthodox Church (Michalski, 1993, p. 73), criticizing it mainly for iconodulism, invocation of saints, and falsification of miracles (Lasicki, 1582, pp. 2-4).

In the meanwhile, the tight anti-Catholic political cooperation between the Orthodox and Protestant nobility had been shaping in the Polish-Lithuanian Commonwealth that was officially agreed in 1599 in Vilnius (Kneifel, 1962, p. 62). The question of the theological influence of Protestant doctrine on the Ruthenian Orthodox writing at the end of the 16 th - the beginning of the seventeenth century remained practically not researched. It is remarkable, however, that the first polemical answer on the Polish Jesuit Piotr Skarga's book Obrona synodu Brzeskiego from the Orthodox side was given by a famous Protestant leader Martin Broniowski (1568-1624). He not only defeated the right of the Orthodox Church to exist but also contained the theological refutation of Catholic doctrine from "the Orthodox" (Protestant in fact) point of view (Stradomski, 2003, p. 32). In 1634, one of the main allegations against Orthodox schools, opened by the Metropolitan Petro Mohyla, was a reproach in the "Protestant deviations" (Голубев, 1898, p. 62). Tight Orthodox and Protestant cooperation continued throughout the 17th century and led even to the cases of conversions of Protestants to the Orthodoxy. The most famous of them was the Lutheran theologian Adam Zernikaw (1652-1693) who in 1680 converted to the Orthodoxy, moved to Ruthenia, took monastic vows in Chernihiv, and became famous for his anti-Catholic treatise De processione Spiritus Sancti a suo Patre (1682) (Bidnov, 1934). Another example might be the hypothetical Protestant descent of Innocent Gizel whose support helped Religiosae Cryptae to see the light of the day.

\section{Dogmatic of the Orthodox Church From the Herbinius' Point of View}

John Herbinius (1633-1679) was a well-known Lutheran theologian and writer. Living long time on the territory of Polish-Lithuanian Commonwealth (in contemporary Vilnus), he wrote a description of the Kyiv religious caves, which was published in 1675 in Jena. In this book, Herbinius, being deeply connected with the West-European Protestant world and at the same time living in multicultural and multi-religious Vilnius, tried to maneuver between the religious tolerance and confessional loyalty, the adherence to the ideas of German reformation and a personal friendship with the Orthodox clergy: Martin Woloszowycz and Innocent Gizel.

Here, it should be reminded that the question of Filioque is one of the oldest and most important in the polemics between Eastern and Western Christianity. The statement that the Holy Spirit proceeds both from the Father and the Son (Filioque) was added to the Niceno-Constantinopolian Creed during the Middle Ages first in Spain and was slowly adopted on the whole Christian West (Oberdorfer, 2009, p. 5). The addition, however, 
was not accepted by Byzantine theologians and provoked a century-long discussion between Western and Eastern Churches.

The strongest opposition towards the idea of Filioque showed Constantinople Patriarch Photios I (ca. 810-893). Photios's Second Letter (Ep. 2, Letter to the Eastern Patriarchs) and "Mistagogy about the Ascension of the Holy Spirit" contained the statement of position against the Latin doctrine of Filioque; it used two main groups of arguments: ecclesiological and theological. The first ones include: the Allusion to the Evangelical Places Jo $15: 26$, and the analysis of the places of Jo. $16: 15$, Gal $4: 6$ which was used by the adversaries to testify to the origin of the Spirit from the Son. Here, Photios also refuted the assertion that Augustine and Jerome took the double ascent of the Spirit, writing about the inaccuracy of the interpretation of their works. In addition, the Fathers could also be mistaken, said Photios. Instead, he called the authority of Popes Damascus, Leo I, John VIII, and Hadrian I. The theological arguments were: the double-procession (aitia) of the Holy Ghost signify two Gods, and hence polytheism; the double ascent of the Spirit mixes and confuses the hypostasis; dual origin humiliates the Holy Ghost (Kolbaba, 2008, pp. 95-99).

Another 9th century Byzantine author, who opposed Filioque, was Nikita the Byzantine who noted that the idea of a double ascension of the Holy Spirit violated the harmony of relations in the Holy Trinity. In addition, wrote Nikita, the double procession denies the Father's and the Holy Ghost's perfection. Nikita also mentioned the idea about the grandson, which arises from the adoption of the idea of double procession (Kolbaba, 2008, pp. 124-128). Later, Filioque provoked a plenty of theological discussions between Catholic and Orthodox authors and became one of the core of ecumenical projects: the Union of Lyon (1274), the Union of Florence (1439), and the Union of Brest (1596).

The Wittenberg Reformation adopted the teaching of Filioque, considering it to be a part of the doctrine of the primary Church. In such a way, the teaching was defended by Tübingen Lutherans in their correspondence to the Patriarch Jeremiah II Tranos. In this discussion, the Patriarch argued that Filioque had changed the Nicene Creed adopted on the first Council of Nicaea 323, and asked for the explanation of Lutheran teaching on the Holy Trinity. In their answer, Tübingen Lutherans, quoting Historia Ecclesiastica by Socrates of Constantinople and other patristic sources, contended that the Council of Nicaea had not proclaimed any doctrine on the problem expressly and the statements of any ecumenical council are not unchangeable. Concerning the question about the Holy Trinity, the protestant theologians appealed to the Holy Scripture and lack of clarity of this problem for a human reason. In general, the controversy of the procession of the Holy Ghost was rather superficial and was not strictly about teaching on the Trinity or Pneumatology. According to D. Wendebourg, the core of the misunderstanding between the Patriach Jeremiah and Tübingen theologians was the different vision of God's presence in the history of Salvation: whereas for the Orthodox theology God is present as a Holy Trinity in eternity, the history of Salvation for the Lutherans is God's presence in the world (Wendebourg, 1986, pp. 213-217).

In polemics of Herbinius with the prior of the Vilnius Orthodox Cathedral of the Holy Spirit Martin Wolossowycz, the last doubted the correctness of Greek texts that were in possession of the Western Christians. The Acts of Councils and Athanasian Creed (the most valuable argument in the Catholic defense of Filioque), argued Wolossowycz, had been falsified by western theologians who hate Orthodox. Therefore, he wanted to discuss the question, using solely his own texts: 
Disputans enim quodam tempore Vilnae cum venerabili Domino Abbate supra saepius laudato Woloszczowicz de processione Spiritus S. cum post evictam ex literis sacris Spiritus S. a Patre et Filio processionem, conciliorum quoque Nicaeni, Constantinopolitani, symboli Divi Athanasi, nec non S. Basilii autoritatem in testimonium adducerem; ille, objecto falsi crimine, omnes Graecorum Patrum libros, Conciliorum decreta adeoque et Symbolum S. Athanasii, ab Ecclesiam Occidentali, odio Orientalium Graecorum corrupta esse contendebat, nec se nisi ex ipsorum Graeco-Ruthenorum libris, quos solos esse sibi intemeratos, convinci volebat. (Herbinius, 1675, pp. 146-147)

The same was Wolossowycz's reaction to Herbinius' intention to discuss another "articles of faith" (Herbinius, 1675, p. 147).

\section{Church Customs, Confessional Views and Canonical Law of the Orthodox Church in Religiosae Cryptae}

Herbinius noticed that among Orthodox the exclusivist views on their religion are very popular; only Eastern Churches were considered by them to be of a right faith, while Western ones were spurious and filthy: Religionis suae Tenacitas, atque Constantia ea ipsis est, ut solas Orientales Ecclesias, versa et puritate Apostolica gaudentes, se quoque solos Orthodoxos, solos Christianos ingenuos; Occidentales vero Ecclesias atque Christianos spurios atque impuros esse censeant. Even the Slavic greeting Prawoslawny that was in use in the everyday communication among the Orthodox in the Polish Lithuanian Commonwealth means nothing else but orthodox and canonical (Herbinius, 1675, p. 149). Such exclusivist position is strictly criticized by the Protestant author who as it was shown above had little confessional restriction: Theologi Graeco-Rutheni falso, atque adeo malo nixi principio, solos se Orthodoxiae nomine celebres atque Canonicos Christianos (Herbinius, 1675, p. 160).

The confessional exclusivism of the Moscow Church developed to that extend that the Lutherans were not even allowed in the Orthodox Churches and monasteries in the Duchy of Moscow; along with the Catholics they had to be rebaptized in the case of conversion, mentioned Herbinius (Herbinius, 1675, p. 150). The popular practice of the rebaptizing in the Duchy of Moscow is proved by plenty of sources; moreover, it concerned not only the Protestants or Catholics but even Orthodox Greeks (Опарина, 2004). Being a Protestant, however, did not prevent Herbinius' visits to the Orthodox churches in the Polish-Lithuanian Commonwealth. In particular, he stressed that he had visited the Orthodox ceremony of baptism, where he had experienced circa Liturgiam rationem administrandi sacramentum COENAE DOMINICAE, lotionem pedum die viridium: Copulationem Neogamorum: Horas canonicas aliosque Graeco-Ruthenorum ritus Ecclesiasticos (Herbinius, 1675, pp. 145-146). While in Moscow the gentiles had to be rebaptized, in the Polish-Lithuanian Commonwealth it was enough to perform a public rejection of the mistakes. Herbinius described this procedure as well referring the Petro Mohyla's "Euchologion":

adeoque Lutherani nostri, quos illi Saxones, et Reformati, quos Calvinianos vocant, ejurare duntaxat pravos sua opinione coguntur: quo facto, precibus, aliisque paucis admodum ceremoniis adhibitis, in Ecclesiae suae gremium nullo negotio eos recipient, moxque Orthodoxiae nomine celebres sive Canonicos appellant. (Herbinius, 1675, pp. 150-151)

On the contrary, the attitude of Ruthenian Orthodox towards those, who had accepted 1596 Union with Rome, is strictly negative: Deficentes vero ab Ecclesiae suae communion diris devovent atque; execrantur. Unde Constantinopolitanos inter et Romanos, quos Unitos, sive Latino-Ruthenos cum Ecclesia Romana vulgo vocant, internecinum plane tantumque intercedit odium, ut ne umbram quidem illorum ferre velint (Herbinius, 1675, p. 151). Here, it should be reminded that by Herbinius' times Ruthenians had survived the bloody 
Cossacks' war and the situation with the rites of the Orthodox Church in the Polish-Lithuanian Commonwealth was totally insufficient from the Orthodox hierarchs' point of view. Let us have a look on it.

After the effective completion of the negotiations with Rome, main part of the Orthodox hierarchy signed the 1596 Union on the Council in Brest. Though the adversaries of Union received in Polish-Lithuanian Commonwealth an outlaw status, some of the monasteries, brotherhoods, and bishops launched an active polemical campaign against it. Antiunion campaign has significantly increased after the resumption of Orthodox hierarchy in 1620, when the Patriarch of Jerusalem Theophanes proclaimed a new Orthodox Metropolitan for Kiev. In 1632-1633, the Orthodox Church was officially rehabilitated in its rights. Yet, the Uniat Church was not abolished; moreover, it had already gained a considerable support and preserved a great part of monasteries, churches and latifundia in Ruthenian lands (mainly on the territory of contemporary Byelorussia). That time onwards there were two official Churches of Eastern rite in the Polish-Lithuanian Commonwealth that provided a polemical Rus' against Rus' campaign. Orthodox Church found, however, a military support in Ukrainian Cossacks. Since Cossack Hetman Bohdan Khmelnytsky started his war against the Polish gentry in 1648, the question of possession of equal rights by the Orthodox was raised on every Diet. Khmelnytsky, aiming to create Cossack autonomy with a predominant role of Orthodoxy and totally prohibit the Union, asked the Tsar of Moscow for a political protection. In Moscow, the decision to incorporate Ukrainian territories and to wage war against Poland was approved and the fight "for the rites of the Orthodox Church" became a matter of international politics. However, pro-Moscow tendencies among Kyiv Orthodox clergymen were relatively weak and ecclesiastical hierarchs did not sign the Bohdan Khmelnytsky's appeal to the Muscovy Tsar about Ukraine becoming part of the Muscovy Tsardom. Kyiv Metropolitan Sylvester Kossov continued the negotiations with Warsaw, aiming to stay in the Polish-Lithuanian Commonwealth. As a result, the treaty of Zboriv (August 18, 1649), guaranteed Kossov and the two Orthodox bishops seats in the Polish Senate that actually meant the total emancipation of the Orthodox Church. In the situation of a full legalization of the Orthodox religion, the Catholic hierarchy built the strong opposition and even though the threat of war against Moscow became a reality, Polish nobility and clergy did not want to allow the Orthodox metropolitan to take the place in the Senate. In the case they had done it, Catholicism would have lost its status as state dominant religion and a Union with Rome would have totally lost its adherents. This is the very historical background on which the Religiosae Cryptae was written. Herbinius' book reflected his correspondent Innocent Gizel's negative attitude towards Uniats and Roman-Catholics that, however, had less to do with the dogmatic contradictions but was mostly provoked by political situation and negative experience of Orthodox hierarchs to emancipate their Church in the Polish-Lithuanian Commonwealth. Herbinius mentioned those historical circumstances as well, underlining the confessional character of Khmelnytsky's war (Herbinius, 1675, p. 152).

Herbinius considered Ruthenians were so much convinced of the rightness of their ancestral religion that only few of them decided to abjure it (Herbinius, 1675, pp. 149-150). This statement, however, might be a simple idealization made by the Protestant author describing the pious Ruthenians: In the 16th and 17th centuries, repeated conversions were part of everyday life of the noble in the Polish-Lithuanian Commonwealth; Ruthenian nobility had been converting both to Protestantism and Catholicism and only petty gentry had been staying in the "fathers' religion" (Яковенко, 2002). Only taking into account the whole Ruthenian early-modern society, including peasants and townspeople, Herbinius calculation of converts could be understandable: de mille Ruthenos, certe vix unus a Religione sua degenerabit (Herbinius, 1675, p. 150). 
Herbinius was astonished at the strictness of the Orthodox Church discipline concerning excommunicated people that could result in to the refusal of the worthy burial until culprit's friends convince the land authority to deny an excommunication and to allow the Church funeral on the cemetery. Such practice, noticed Herbinius, leads to both sorrow and joyful importance of such cases in the Church:

Nec minus est stupendus ipsorum Disciplinae Ecclesiasticae rigor atque vigor: ac praecipue excommunicatio peremptoria sive Bannum majus, quo sacrilegii, aut alius cujuspiam criminis magni reus, in facie Ecclesiae, a Praesule ritibus ad terrorem compositis, excommunicatur publice ita, ut, ni resipuerit mature, etiam post mortem Banni illius fulmine percussi hominis corpus terram indignum insepultumque maneat, donec precibus amicorum exoratus Praesul excommunicatum reum a Banno illo peremptorio publice denuo atque solenniter absolverit: quo facto, ab Ecclesia, magna tum doloris ac simul laetitiae significatione, justa ei demum funebria in Coemiterio persolvuntur. (Herbinius, 1675, pp. 148-149)

In fact, great excommunication, anathema, in the Orthodox Church was applicable only to the most serious crimes: heresy, apostasy, and sacrilege. The great excommunication is the complete exclusion from the Church

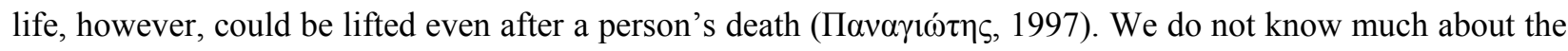
excommunicative practice in the Orthodox Church of the Polish-Lithuanian Commonwealth. Obviously, the cases of excommunication because of a heresy (conversion to another religion) occurred quite often. Described by Herbinius practice of friends' interaction for church burial of the gone culprit totally agreed with the well-known mutual support that existed among Polish szlachta's corporation. This posthumous aspect of the excommunicative practice having not existed in the Lutheran Church astonished the Protestant author most of all.

\section{Eastern Rite, Sacraments, and Piety in the Religiosae Cryptae}

Herbinius explained to the Protestant reader some specific elements of Eastern rite, piety, and sacraments. The core of the Orthodox ecclesiastic life-liturgy-he described as long and more elegant than the Catholic one. Herbinius paid a lot of attention to the Orthodox liturgical songs, praising them for the harmony and polytonality: Musica in qua Discantus, Altus, Tenor et Bassus, harmonia suavissima et Sonora distincte audiuntur (Herbinius, 1675, p. 153). Herbinius compared the simplicity and harmony of the Orthodox singing with his beloved music of the Protestant composer Johann Stobäus (1580-1646) and opposed it to the expressive Renaissance and Baroque music written by some Italian or French composers (Herbinius, 1675, pp. 155-156). Moreover he considered the Orthodox Ruthenian singing to be close to the primer Christian liturgy:

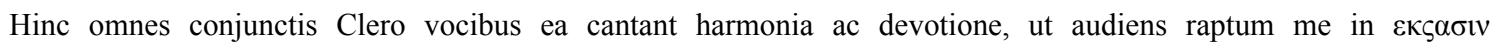
Hierosolymis esse, primitivaeque ibi Christianorum Ecclesiae faciem atque spiritum videre mihi viderer, eoque nomine Filium Dei, sacrorum Ruthenicorum simplicitati illachrymando, ex Symbolo Divorum Ambrosii et Augustini laudavi, inquiens: Pleni sunt coeli et terra Majestatis gloriae tuae! (Herbinius, 1675, p. 157)

Remarkable and positively treated by the Protestant author was the fact of using of vernacular language during the liturgy: Intellegit apud eos plebs promiscua, quae Clerus lingua Sclavonica vernacula aut canit, aut orat (Herbinius, 1675, p. 153). Therefore, Herbinius openly appealed to the Protestant reader to imitate the simplicity of Greek and Slavic liturgical songs (Herbinius, 1675, p. 157). At the same time, Herbinius mentioned Ruthenians' apathy towards the Church preaching and evangelising. Only written homilies of the Fathers but not a spoken word of the priests could inspire some respect among the listeners, mentioned Herbinius: 
si Mysta sacer concionem in Ecclesia recitaret ex memoria, Rutheni eum mentiri existimarent, adeoque somnia et mendacia sua proponi sibi indignarentur. Si vero ipsis ex libro praelegeris homiliam, omnes te, aperto capite, manibusque complicatis, stantes vel bipennibus suis innixi, subindeque suspirantes, audient attentissime. (Herbinius, 1675, p. 158)

Herbinius also emphasized the Communion sub utraque specie and its similarity to Lutheran one (Herbinius, 1675, p. 87). However, the specific of Orthodox Eucharist is more important. Herbinius described in detail the shape and inscriptions on the Holy Host ( $\pi \rho \circ \varsigma \varphi \rho \rho \circ)$ ) and gives a Protestant reader the image of it (Herbinius, 1675, pp. 85-86). It should be mentioned here that this image is a unique source of information about the Host-baking in Lavra in the middle of the 17th century. He mentions instead a practice of carrying the Host by laics home as a commemoration of the Holy Sacrament. This practice Herbinius observed himself (probably during his visit to Moscow) as he skeptically mentions the participation in the ritual of small children as well: inter quos [sacri epuli convivis] etiam infantes bimulos non sine stupor observavi (Herbinius, 1675, pp. 87-88).

Explaining the double-usage of the Host, Herbinius referred to Jacques Goar's E'́xolóylov that contained two interpretations of the Holy Bread: as Eucharist bread and a substance for a special monastic Marian prayer (the so-called panagia) (Goar, 1730, p. 101). However, the last one is not retold by the protestant author. The omitting of the information about panagia could be explained by Herbinius' caution towards Orthodox Marian piety.

Eastern Christianity pays a special attention to the veneration of the Mother of God and her icons. Due to the fact that Marian cult was strongly promoted at the beginning of the 17th century, the most popular in Orthodox churches in the Polish-Lithuanian Commonwealth were the icons of Mother of God. Kyiv Pechersk Lavra was not an exception. There has been venerating the icon of the Dormition of Virgin Mary.

The attitude of Protestants towards Marian piety has become an objective of several recent studies. Martin Luther in his commentary to medieval song Magnificat stressed that Maria earned no merits because of her humility to become the Mother of God; she is also not an example for imitation, said Luther. However, he continued to use such objectives concerning her as pure and loving and the commentary already in the 16th century became the kind of bridge in the Catholic-Protestant dialogue (Burger, 2007, pp. 19, 182). Whereas at the beginning of the Reformation reformers tried to reduce the role of Mary in the history of Salvation, that was highly praise in Medieval practices, and the attitude towards Marian cult became a kind of confessional detector (Christman, 2015, pp. 408-410), later Marian imagery was broadly presented in Lutheran churches (Crăciun, 2012).

Herbinius' attitude to Marian cult is not totally clear. When he mentioned the dedication of the main monastery church he used such definition as templo Divae Mariae virginis Deiparae (Herbinius, 1675, p. 113). In another place of his work, he mentioned wreath of Mary-sertum Deiparae Virgini sacrum. These direct translations of the cult, popular in the monastery, however, do not allow asserting that Herbinius accepted the idea of uncorrupted virginity of the Mother of God. Herbinius mentioned the icon of a "Kyivan Heaven" represented Caves Fathers as heaven stars in the wreath of Mary (Herbinius, 1675, pp. 113-114). This is a typical metaphor of Ukrainian early Baroque literature where the saints were associated with the celestial bodies. Such depiction of the Virgin really existed on the wall of the Lavra's main gate and eventually was spread among the pilgrims as an engraving.

However, it does not mean Herbinius did demonstrate positive attitude to church depictions. On the contrary, he described it as great superstition of the Orthodox piety that in Moscow developed into the people 
believed that icons were alive (Herbinius, 1675, p. 166). He called the veneration of icons barbaric and criticized counterarguments of the Orthodox side: Accusati vero de sua plus quam Barbara Iconolatria excusant eam vehementer, docentque se non colere statuas, sed sacras duntaxat Deiparae Apostolorum et

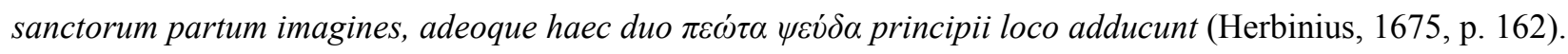
Both arguments of the Orthodox theologians-that icons are not statues and iconolatry does not mean idolatry-did not convince the Protestant author. He could agree that there were some depictions in the early Church, this fact, however, did not justify in his eyes the idolatry. Here relied on the ecclesiastic authority of Epiphanius of Salamis (310-403) to whose authority traditionally referenced the Protestant authors in their polemic against veneration of icons (Michalski, 1993, p. 110). The main source of the theological argumentation for the Orthodox theologians-the second Council of Nicaea (787)—was not trustworthy for Herbinius due to the Byzantine imperators headed it: Qui lethalis Ruthenorum catatthus ab Imperiali Irenes matris cum Filio Constantino VI. in Oriente regnantis capite profluxit (Herbinius, 1675, p. 164). Moreover, he considered the decision of the Council to be denied by the 794 Council in Frankfurt assembled by Charles the Great (Herbinius, 1675, p. 165).

\section{Monastic Life and the Orthodox Clergy in Religiosae Kijoviensium Cryptae}

Herbinius noticed the great respect paid by Ruthenians to the Orthodox clergy and aimed to look at it precisely in a separate paragraph:

Praeterea tanta Reverentia sacerdotes suos (Sclavonice Pop dicuntur) colunt, ut Angelorum vicem eos revereantur, dictoque ipsorum sint audientissimi. Hinc etiam promiscuos sacerdotes, raro aut nunquam nominibus propriis, semper autem summis fere Pontificum titulis, Venerabiles, Deiferos, Sanctos, Patres, beatosque semper cernui atque humiles, salutant: ipsorum studia et conciones sunt illis cogitationes Dei (Herbinius, 1675, p. 159).

In general, Herbinius' attitude towards Orthodox clergy is positive; he considered it to be totally different from the Roman Catholic one: They do not sale indulgences, relics of saints, altars, icons, statues; they do not proclaim a teaching on Purgatory and serve private masses, the only one donation they took is free-willing door tax (eleemosynae ostiariae). Because of such unmercenariness, Herbinius highly appreciated Orthodox clergy:

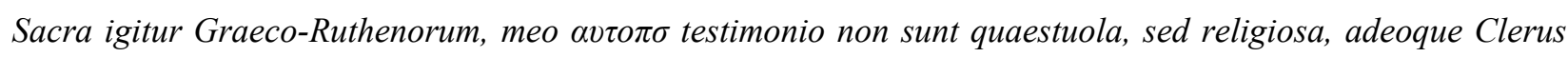
ipsorum ab operis mercenariis quaestuque Simoniaco plane alienus est (Herbinius, 1675, p. 135). At the same time, however, he criticized the ignorance of the Orthodox priests and their pretending to the God's name "Lord" (Dотіпия, Владика):

Tanti aestimant Rutheni suos Praesules et Sacerdotes, qui tamen plerumque rudes scientiarum ac inertes, praesertim in Moscovia, sunt; secus ac quidem apud nos quidam Politici male feriati Pastores animarum suarum vocant Dominos, quo titulo ipsos tacite illudunt, eosque habent despicatui, ignari Christum omnia haec opprobria in se transcripturum, atque olim severe vindicaturum. (Herbinius, 1675, p. 160)

Herbinius' book was focused on the monastery of the caves. Though he rarely used the term monasterium (Herbinius, 1675, p. 30), mainly writing about caves as separate phenomenon, he touched with the problem of monasticism very closely. The issue of Protestantism and monasticism is one of the most complicated in Church history (Jaspert, 2005, p. 49). From the very beginning, the reformation had a problem with the recognizing of Christian monasticism despite the fact that many of reformers were monks themselves. According to some authors, Martin Luther just wanted to reform the monastic life, struggling against 
monasteries misusage for matrimonial policy (Vinken, 2016, pp. 411-413). In his 95 thesis, Luther emphasizes the repentance as a goal of all Christians and therefore equalizes monastic and laic life. However, he rejected monastic life himself and criticized monasticism in his Work De votis monasticis iudicium. Not denouncing the Biblical meaning of vows in general, he doubted the soteriological meaning and exclusivism of the monastic vows (Jaspert, 2005, p. 61). He had nothing against monks' lifestyle, but he could not accept the idea of the special power of monks' prayer and saw in monasticism a danger for evangelical freedom. In general, his critique of monasticism was stronger than his appeals to renovate the monasticism according to reformed theology (Jaspert, 2005, p. 63). As a result of the discarding of monasticism as the unique form of Imitatio Christi, plenty of monasteries and nunneries were closed and the rejection of the monastic vows both by men and women became a common thing in the 16th century reformed Europe; many of monasteries were turned into schools or evangelical foundations (Schuster, 2016, p. 9).

The Confession Augustana (CA 27) flayed monasticism, criticizing its concerning as contract matrimony, exaggeration of the importance the monastic vows and their interpretation as a way to Christian perfection. Haec omnia, cum sint falsa et inania, faciunt vota irrita. This very statement of the Confession provoked the strongest disagreement between Tübingen theologians and Patriarch Jeremiah II. The later undoubtedly interpreted the monasticism as an ideal of Christian life and proved his opinion with Acts of the Ecumenical Councils and patristic literature. According to Jeremiah, the celibacy is easier way to Salvation than marriage, laics life is not a perfect Christian life, and the world is a strong rival in human's way to God. Answering these arguments, Tübingen Lutherans agreed that there are a lot of pious Christians among the monks; monastic vows, however, must be denied as unnecessary for the perfect Christian life and a marriage is simply a kind of God's call (vocatio) to serve a Christian duty (officium), they insisted (Wendebourg, 1986, pp. 266-271).

The common attitude of the Protestants towards Orthodox monasticism was, however, far away from total imperception. Moreover, often they admire their pious behavior and a strict life, e.g., Martin Zeiller wrote on the Orthodox monks whom he observed during his travel to Kyiv following:

Es führen diese Mönch ein gar hartes Leben und zur Fastenzeit, gehen sie in Höline oder Löcher, unter der Erden und thun da selbsten in der Einöde Buß. Andere begeben sich in die Wildnüsse, mit einem härinen Kleid und eisenen Ketten angethan; bißweilen gar weit in die Tartarey, da sie das Evangelium predigen und darüber getödet werden. (Zeiller, 1657, pp. 144-146)

Writing about the inhabitants of the Caves, Herbinius used mostly the expressions vir religius, vir sacer, heros, or pater, very rare sanctus or martyr and only several times monachus (Herbinius, 1675, p. 61). He explains to the reader also the Slavic terms inok (from Latin unicos) and czerniec (from Polish czarny-black) (Herbinius, 1675, p. 68). Sometimes, the Orthodox monks are called by Herbinius the order of St. Basilius (Herbinius, 1675, p. 38) that was a very popular definition in the Polish-Lithuanian Commonwealth; the term ihumenus is explained through Catholic analog abates, prior, and the Protestant one Probst (Herbinius, 1675, pp. 66, 84). Herbinius also repeated a definition that was very popular in both Catholic and Orthodox spirituality, describing monks as terrestrial angels and humans at the same time: angelos terrestres atque homines. Moreover, he applied it to his biggest ecclesiastical authority-Martin Luther (Herbinius, 1675, p. 27). Thus, the author can assume that Herbinius saw the monastic life totally positively. It could be assumed, eastern monasticism with its individualism and lack of strict common-life rules was more attractive for Herbinius than catholic monastic orders. However, there is not any negative attitude regarding catholic monks either. Writing 
about Luther's cell in former Augustinian monastery in Magdeburg, he mentions pure tired monks, who were lying on Luther's bed to take a rest (Herbinius, 1675, p. 72).

Herbinius several times mentions monks as reading Psalms and praying (Herbinius, 1675, pp. 65, 84). Herbinius underlines this by very simple reason-in Martin Luther' theology and life prayer and Psalms prayed a tremendous role (Haemig, 2016). Among other monastic practices he mentions exhausting a body with fasting and wakefulness, voluntary enclosing in caves with only bread and vegetables. However, such practices, mentions Herbinius, had to be approved by the abbot (Herbinius, 1675, pp. 65-66). He explains the popular among caves fathers practice to enclose themselves in the caves as coursed by private piety (religionis privatae gratiam), however, mentions Herbinius, monks were supplied with food and other necessities (Herbinius, 1675, p. 84). It should be mentioned that Herbinius does not mention the strictest ways of monastic feats, mentioned in Patericon-some monks had dug themselves and were starving for several days.

Herbinius gave monastic ascetical practices very positive evaluation, he admires religiosity and piety of former Christians, and even regrets about lack of them among contemporaries. However, he is also aware that mentioned religious practices in his times are controversial and under discussion between the adherents of fasting and opponents of everything: sed hodie nobis veterum pietas ac religio obsolescit, nostra autem juniorum aut jejuna nimis est, aut omnino nulla (Herbinius, 1675, p. 66).

It is important that Herbinius has completely omitted the problem of monastic vows that as the author has mentioned above, was very drastic for the Protestantism, and gave two reasons for monastic practices: expiations of sins and earning merit that is called an error that Orthodox and Catholic have in common (Herbinius, 1675, p. 85).

Thus, during his stay in Vilnius Herbinius was opened for theological debates with the Orthodox clergy about the questions of dogmatic. Yet, unwillingness of the Orthodox clergy to discuss the problem Filioque apart from using their own sources made Herbinius attempts insufficient. In general, the Protestant author percepted and treated the Orthodox Church in a very positive way: Church customs, canonical law, and discipline, clergy and even monasticism did not provoke any criticism from his side. However, on the questions of iconolatry and confessional exclusivism of the Orthodox Church Herbinius could not refrain from criticism. They evidently contradicted his own views on real Christian piety and religious tolerance.

\section{References}

Benz, E. (1952). Die ostkirche im lichte der protestantischen geschichtsschreibung von der reformation bis zur gegenwart. Freiburg, München: Alber.

Bidnov, V. (1934). Zur geschichte der deutsch-ukrainischen kulturellen wechselbeziehungen ende des 17 jahrhunderts. Elpis, 1, 151-174.

Burger, C. (2007). Marias lied in Luthers deutung: Der kommentar zum magnifikat (Lk 1,46b-55) aus den jahren 1520/21. Tübingen: Mohr Siebeck.

Christman, R. (2015). The Marian dimension to the first executions of the reformation. Church History and Religious Culture, 95(4), 408-434.

Crăciun, M. (2012). Marian imagery and its function in the Lutheran churches of early modern Transylvania, In A. Spicer (Ed.), Lutheran churches in early modern Europe (pp. 133-164). Farnham: Ashgate.

Goar, J. (1730). Euchologion: Sive rituale graecorum complectens ritus et ordines divinae liturgiae. Venetiis: Ex Typographia Bartholomei Javarina.

Haemig, M. J. (2016). Luther on prayer as authentic communication. Lutheran Quarterly, 30(3), 307-328.

Herbinius, J. (1675). Religiosae kijovienses cryptae, sive kijovia subterranea: In quibus Labyrinthus sub terra, et in eo emortua, à sexcentis annis, divorum atque heroum graeco-ruthenorum, \& nec dum corrupta corpora. Jenae: Hallervordus. 
Jaspert, B. (2005). Mönchtum und protestantismus: Probleme und wege der forschung seit 1877. Band 1. St. Ottilien: Eos-Verl.

Kneifel, E. (1962). Geschichte der evangelisch-ausburgischen kirche in polen. Niedermarschacht über Winsen/Luhe: Selbstverl. d. Verf.

Kolbaba, T. M. (2008). Inventing heretics: Byzantines and the Filioque in the ninth century. Kalamazoo, Mich.: Medieval Institute Publication.

Łasicki, J. (1582). De russorum moscovitarum et tartarorum religione, sacrificiis, nuptiarum, funerum ritu: Ex diversis scriptoribus ... his in fine quaedam sunt adiecta, de Livonia pacisque conditionibus. Spirae.

Lemberg, H. (1985). Zur Entstehung des Osteuropabegriffs im 19. Jahrhundert. Vom "Norden” zum “Osten” Europas. Jahrbücher für Geschichte Osteuropas, Neue Folge, 33(1), 48-91.

Michalski, S. (1993). The reformation and visual arts: The Protestant image question in Western and Eastern Europe. London: Routledge.

Oberdorfer, B. (2009). Filioque. In H. D. Betz (Ed.), Religion, past and presence: Encyclopedia of theology and religion (Vol. 5). Leiden: Brill.

Pichler, A. (1862). Geschichte des Protestantismus in der orientalischen Kirche im 17. Jahrhundert oder: Der Patriarch Cyrillus Lucaris und seine Zeit, München.

Schuster, A. (2016). Die geschichte des klosters hornbach und seine entwicklung zur landesschule im 16. Jahrhundert. Blätter für Pfälzische Kirchengeschichte und Religiöse Volkskunde, 83, 9-42.

Stradomski, J. (2003). Spory o “wiare greckq” w dawnej rzeczypospolitej. Kraków: Wydawnictwo Scriptum.

Vinken, B. (2016). Emanzipation durch die reformation?, Lebendige Seelsorge, 67(6), 411-413.

Wendebourg, D. (1986). Reformation und orthodoxie: Der ökumenische Briefwechsel zwischen der Leitung der Württembergischen Kirche und Patriarch Jeremias II. von Konstantinopel in den Jahren 1573-1581 [Forschung zur Kirche und Dogmengeschichte, Band 37]. Göttingen : Vandenhoeck \& Ruprecht.

Westphalus, J. (1555). Adversus cuiusdam Sacramentarii falsam criminationem, iusta defensio. Francoforti: Peter Braubach.

Zeiller, M. (1657). Anderte beschreibung des königreichs polen und großherzogthums litauen; Aus den neulichsten Polnischen und andern Scribenten aufs neu nach den unterschidlichen Ländern zusammen getragen und auf diese gegenwertige Zeit gerichtet; wie aus der Vorrede zuersehen. Ulm : Wildeysen.

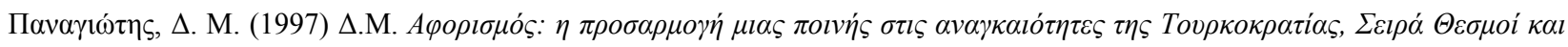

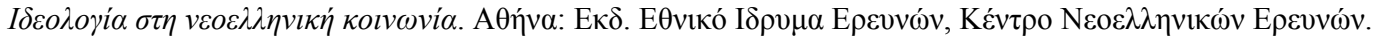

Голубев, С. Т. (1898). Киевский митрополит Петр Могила и его сподвижники. Т. 2. Киев: Тип. С. В. Кульженко.

Опарина, Т. А. (2004). «Исправление веры греков» в русской церкви первой половины XVI в. Россия и Христианский Восток, 2-3, 288-325.

Синицына, Н. В. (1998). Третий Рим. Истоки и эволюция русской средневековой концепции (XV-XVІвв.). Москва: Индрик.

Яковенко, Н. (2002). Релігійні конверсії: спроба погляду зсередини. In Н. Яковенко (Ed.), Паралельний світ: Дослідження з історії уявлень та ідей в Україні XVI-XVIII cm (рp. 13-79). Київ: Критика. 